\title{
THE INFLUENCE OF URBAN LAND USE ON THE WATER QUALITY OF OTAMIRI RIVER FOR MUNICIPAL SUPPLY
}

\author{
Onosakponome, Ogaga Robert \\ Department of civil engineering, Federal University of Technology, \\ Owerri, Imo State, Nigeria
}

\begin{abstract}
Water quality levels of Otamiri River was studied to seek explanations for the variations of water quality indicators in the river and also tried to evaluate the influence of urban land use activities and season on the water quality and to examine the water quality of Otamiri River for agricultural and domestic uses. Water sampling and laboratory analyses were carried out using standard procedures to determine the concentrations of selected parameters in the sample. The data obtained ranged from 21.10 to $98.00 \mu \mathrm{S} / \mathrm{cm}$ for Electrical Conductivity, 9.70 to $45.10 \mathrm{mg} / \mathrm{l}$ for TDS, 5.60 to $20.80 \mathrm{mg} / \mathrm{l}$ total hardness, 0.00 to $3.06 \mathrm{mg} / 1 \mathrm{NO}^{3-}$, 0.15 to $6.50 \mathrm{mg} / \mathrm{l} \mathrm{PO} 4,0.00$ to $12.63 \mathrm{mg} / \mathrm{l} \mathrm{SO}_{4}{ }^{2-}$, and 14.48 to $32.96 \mathrm{mg} / \mathrm{l} \mathrm{Cl}^{-}$. Other results ranged from 12.03 to $19.26 \mathrm{mg} / \mathrm{l} \mathrm{BOD}_{5}$, TSS 40.50 to $1793.50 \mathrm{mg} / \mathrm{l}$, turbidity 7.86 to $96.40 \mathrm{NTU}$ and $\mathrm{pH}$ 6.48 to 6.90 at $29^{\circ} \mathrm{C}$. The data clearly show that areas outside the influence of urban activities still maintain their pristine environmental conditions with water quality parameters falling within permissible limits. The water from these areas can sustain aquatic life and are safe for human consumption. However, the results further showed that the midstream area that receive wastes from urban land use activities was polluted with parameters such as $\mathrm{NO}^{3-}, \mathrm{PO}^{4-}$ , $\mathrm{Cl}^{-}, \mathrm{BOD}_{5}$, TDS, and COD being higher than the permissible limit. This demonstrates the influence of urban land use on the water quality of Otamiri River.
\end{abstract}

KEYWORDS: Water quality, domestic use, Parameters, Otamiri River, Concentrations, Limit.

\section{INTRODUCTION}

Water, the source of life and human civilization has become one of the major issues in recent years; it is probably the most valuable natural resources available to man, without which no life can survive. Adequate and safe water supply is therefore a prerequisite for significant socioeconomic development of any community [11].
Unfortunately, in many areas of the world, especially developing countries including Nigeria, it is difficult to obtain a steady source of pure water for drinking and agricultural uses. Water related issues were a major source of concern to developing countries and international agencies like WHO, FAO, UNICEF, and UNDP among others. These problems have challenged engineers in the water sector and other stakeholders to effectively develop and manage the water supply system.

The supply of fresh water for domestic and agricultural uses is an important role of rivers, streams, wells and springs. Regardless of the source, water in its natural environment contains some impurities such as dissolved solids and gases. It also hosts a number of micro-organisms; pathogenic and non-pathogenic. The level of its physical, chemical and biological impurities defines its quality which is evaluated relative to the requirement for its intended use.

Large quantity of water is needed for irrigation, power generation, and recreation, industrial and municipal purposes. The largest water requirement is for municipal use but the standard of purity required for this purpose is quite different from that demanded for industrial and commercial use. Clean, fresh water is necessary for drinking, bathing, swimming, and food processing.

In Owerri municipal council, Otamiri River and underground water supply from private boreholes are the main sources of water for domestic and other uses, especially when the public water supply becomes epileptic. Otamiri River drains areas of diverse geology, soils and land use, and like other surface water, the river is liable to pollution from atmospheres and also from the composition of the soils and rocks through which the surface basin filters down into rivers [8]. In addition, pollution of the river can result from human activities such as urban agriculture, dumping of solid waste, and discharge of effluent from industries into the river. Since Owerri urban and its environs depend partly on water from Otamiri River for their domestic, uses, there is a need to assess the quality of the river water. Also of importance are the influence of 


\section{International Journal of Engineering Applied Sciences and Technology, 2021 \\ Vol. 6, Issue 2, ISSN No. 2455-2143, Pages 184-191 \\ Published Online June 2021 in IJEAST (http://www.ijeast.com)}

urban land use activities and seasonal variation on the quality of the water.

Rivers primarily constitute one of the major sources of water supply in the world. The assessment and continuous monitoring of water quality sourced from rivers can be used to define existing conditions, detect trend and/or establish sources of pollution. The quality of water is often affected by natural (e.g., rocks, soils and surface through which it flows) and anthropogenic (e.g., industrial, agricultural and mining) activities [2]. Several studies revealed that these activities coupled with atmospheric factors affect the suitability of water for any purpose [3]. The Otamiri River in Owerri municipal council, Imo State, Nigeria is no exception.

\section{RIVER POLLUTION}

Water is typically referred to as polluted when it is impaired by anthropogenic contaminants. Due to these contaminants it either does not support human use, such as drinking water, or undergoes a marked shift in its ability to support its biotic communities, such as fish. Natural phenomena such as volcanoes, algae blooms, storms, and earthquakes also cause major changes in water quality and the ecological status of water.

Water pollution is the contamination of water bodies (e.g. lakes, rivers, oceans, aquifers and groundwater), usually as a result of human activities. It is often caused by the discharge of inadequately treated wastewater into natural bodies of water [12]. This can lead to environmental degradation of aquatic ecosystems. In turn, this can lead to public health problems. For example, people living downstream may use the same polluted river water for drinking or bathing or irrigation. Water pollution affects the entire biosphere of plants and organisms living in these water bodies, as well as organisms and plants that might be exposed to the water. The effect can be damaging not only to individual species, but also to the natural biological communities [9]. Water pollution can be grouped into surface water pollution (which includes marine pollution) and groundwater pollution. Nutrient pollution is a form of water pollution caused by nutrients and can affect surface water and groundwater.

There are many causes for water pollution but two general categories exist:

- $\quad$ Direct and

- Indirect contaminant sources.

Direct sources include effluent outfalls from factories, refineries, and waste treatment plants etc. that emit fluids of varying quality directly into urban water supplies. In countries like the United States and other countries, these practices are regulated, although this doesn't mean that pollutants can't be found in these waters. Indirect sources include contaminants that enter the water supply from soils/groundwater systems and from the atmosphere via rain water. Soils and ground waters contain the residue of human agricultural practices (fertilizers, pesticides, etc.) and improperly disposed of industrial wastes. Atmospheric contaminants are also derived from human practices (such as gaseous emissions from automobiles, factories and even bakeries). Contaminants can be broadly classified into organic, inorganic, radioactive and acid/base. Examples from each class and their potential sources are too numerous to discuss here.

The effects of water pollution are varied, they include:

- Poisonous drinking water

- Poisonous food animals (due to these organisms having bio accumulated toxins from the environment over their life spans)

- Unbalanced river and lake ecosystems that can no longer support full biological diversity, deforestation from acid rain, and many other effects.

These effects are, of course, specific to the various contaminants [15].

\section{WATER QUALITY}

Water quality refers to the chemical, physical, biological, and radiological characteristics of water. It is a measure of the condition of water relative to the requirements of one or more biotic species and or to any human need or purpose [14]. It is most frequently used by reference to a set of standards against which compliance, generally achieved through treatment of the water, can be assessed. The most common standards used to assess water quality relate to health of ecosystems, safety of human contact, and drinking water.

Water quality assessment begins with water quality standards. States and other jurisdictions adopt water quality standards for their waters. EPA must then approve these standards before they become effective under the Clean Water Act [4]. Water quality standards have three elements: the designated uses assigned to waters (e.g., swimming, the protection and propagation of aquatic life, drinking), the criteria or thresholds that protect fish and humans from exposure to levels of pollution that may cause adverse effects, and the antidegradation policy intended to prevent waters from deteriorating from their current condition [10]. 
After setting standards, states assess their waters to determine the degree to which these standards are being met. To do so, states may take biological, chemical, and physical measures of their waters; sample fish tissue and sediments; and evaluate land use data, predictive models, and surveys.

Drinking water quality standards describes the quality parameters set for drinking water. Despite the truth that every human on this planet needs drinking water to survive and that water may contain many harmful constituents, there are no universally recognized and accepted international standards for drinking water. Even where standards do exist, and are applied, the permitted concentration of individual constituents may vary by as much as ten times from one set of standards to another.

Many developed countries specify standards to be applied in their own country. In Europe, this includes the European Drinking Water Directive and in the United States the United States Environmental Protection Agency (EPA) [4] establishes standards as required by the Safe Drinking Water Act. For countries without a legislative or administrative framework for such standards, the World Health Organization (WHO) publishes guidelines on the standards that should be achieved. China adopted its own drinking water standard GB3838-2002 (Type II) enacted by Ministry of Environmental Protection in 2002. In
Nigeria in 2005, the National Council on Water Resources (NCWR) recognized the need to urgently establish acceptable Nigerian Standard for Drinking Water Quality (NSDQW). Where drinking water quality standards do exist, most are expressed as guidelines or targets rather than requirements, and very few water standards have any legal basis or, are subject to enforcement [13]. Two exceptions are the European Drinking Water Directive and the Safe Drinking Water Act in the USA, which require legal compliance with specific standards.

\section{WATER SAMPLING LOCATIONS AND EXPERIMENTAL DETERMINATION OF PARAMETERS}

Four areas 1, 2, 3, and 4 were selected for sampling along the river. Area 1 is upstream and close to the source, and also acts as control. Areas 2 and 3 are in the midstream and are the areas where urban land use activities have greater impact. Section 4 is downstream with lesser land use impact. The sampling was carried out in the wet season. Four clean plastic containers of a litre capacity were used in collecting the samples. This is done by first rinsing the containers with the river water before collection. Each sample shall be immediately covered and labelled and preserved at room temperature before they were taken to the laboratory.

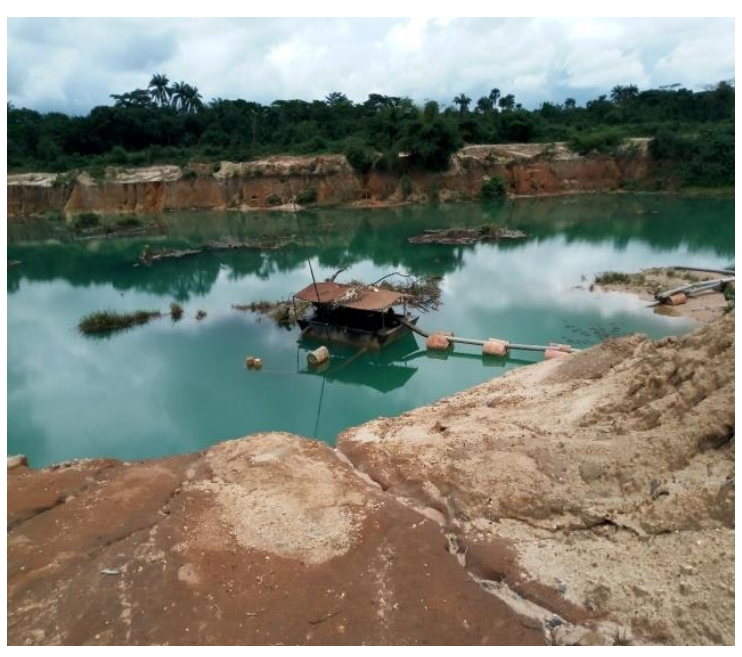

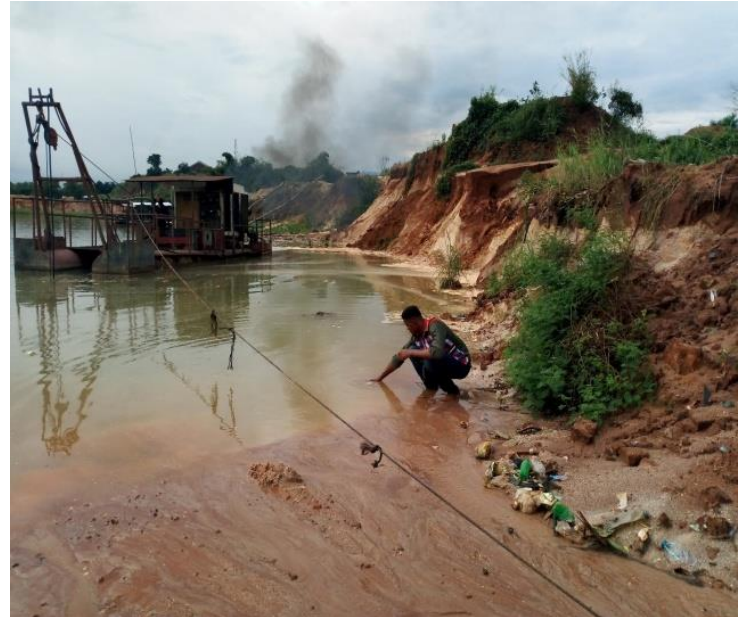

Plate 1: Sample location 1 at Egbu.

Plate 2: Sample location 2

Standard analytical procedures were used in the determination of selected physical, chemical and biological water quality parameters of the sample [1]. The parameters analyzed includes: Iron, Fe, Sulphate, $\mathrm{SO}_{4}{ }^{2-}, \mathrm{Nitrate}^{2}$ $\mathrm{NO}_{3}{ }^{-}$, Phosphate, $\mathrm{PO}_{4}{ }^{3-}$, Chloride, $\mathrm{Cl}^{-}$, Lead, $\mathrm{Pb}, \mathrm{pH}$ at $29^{\circ} \mathrm{C}$, Turbidity, Conductivity, Alkalinity, Total 
Dissolved Solids (TDS), Total Suspended Solids (TSS), Total hardness (as $\mathrm{CaCO}_{3}$ ), Biochemical Oxygen Demand (BOD) and Chemical Oxygen Demand (COD).

\section{RESULTS}

The results of the physical, chemical and microbiological analysis carried out on the various water samples are shown in Table 4.1.

Table 4.1: Concentrations of Otamiri Water Quality Parameters

\begin{tabular}{|c|c|c|c|c|c|}
\hline PARAMIETER & 1 & 2 & 3 & 4 & WHO STANDARD \\
\hline Iron, Fe, mg/l & 0.278 & 0.825 & 0.394 & 1.414 & 0.2 \\
\hline Sulphate, $\mathrm{SO}_{4}{ }^{2-}, \mathrm{mg} / \mathrm{l}$ & 0.26 & 12.63 & 0.00 & 0.00 & 200 \\
\hline Nitrate, $\mathrm{NO}_{3}{ }^{-}, \mathrm{mg} / \mathrm{l}$ & 0.00 & 0.00 & 1.14 & 3.06 & 10 \\
\hline Phosphate, $\mathrm{PO}_{4}{ }^{3-}, \mathrm{mg} / \mathrm{l}$ & 0.15 & 0.65 & 0.17 & 0.24 & 0.1 \\
\hline Chloride, $\mathrm{Cl}^{-}, \mathrm{mg} / \mathrm{l}$ & 14.48 & 30.96 & 32.96 & 20.16 & 250 \\
\hline Lead, $\mathrm{Pb}, \mathrm{mg} / \mathrm{l}$ & 0.00 & 0.00 & 0.00 & 0.00 & 0.05 \\
\hline $\mathrm{pH}$ at $29^{\circ} \mathrm{C}$ & 6.48 & 6.56 & 6.52 & 6.90 & $6.0-8.5$ \\
\hline Turbidity, NTU & 7.86 & 96.40 & 8.09 & 12.38 & 5.0 \\
\hline Conductivity, uS/cm & 47.90 & 98.00 & 27.70 & 21.10 & 100 \\
\hline Alkalinity, mg/l & 16.00 & 8.00 & 8.00 & 8.00 & NS \\
\hline TDS, mg/l & 21.90 & 45.10 & 12.70 & 9.70 & 200 \\
\hline TSS, mg/l & 40.50 & 163.03 & 251.50 & 1793.50 & 50 \\
\hline $\begin{array}{l}\text { Total hardness (as } \mathrm{CaCO}_{3} \text { ), } \\
\mathrm{mg} / \mathrm{l}\end{array}$ & 9.20 & 20.80 & 5.60 & 6.00 & 500 \\
\hline BOD, mg/l & 12.03 & 19.26 & 14.44 & 16.85 & 4.0 \\
\hline $\mathrm{COD}, \mathrm{mg} / \mathrm{l}$ & 33.43 & 53.50 & 40.12 & 46.81 & 40 \\
\hline
\end{tabular}

NS = Not specified

The concentrations of the various water quality parameters varied with the sampling locations in the rainy season.

TURBIDITY: Turbidity values were high during this season (rainy). This was probably due to solid waste material and soil particles transported by runoff from urban activities into the river. Location 2 (Owerri town) see figure 4.1, had significantly
(96.40 NTU) higher value than other locations because this is the area that is contiguous to the urban area and receive direct impact of urban activities such as dumping of solid wastes and sand excavation from the river. The values from locations 2 were higher than the standard limit for drinking water (5.00 NTU). Turbidity affects fish and aquatic life by interfering with sunlight penetration [5]. He was also of the view that drinking water should be free from turbidity on aesthetic grounds. 
International Journal of Engineering Applied Sciences and Technology, 2021

Vol. 6, Issue 2, ISSN No. 2455-2143, Pages 184-191

Published Online June 2021 in IJEAST (http://www.ijeast.com)

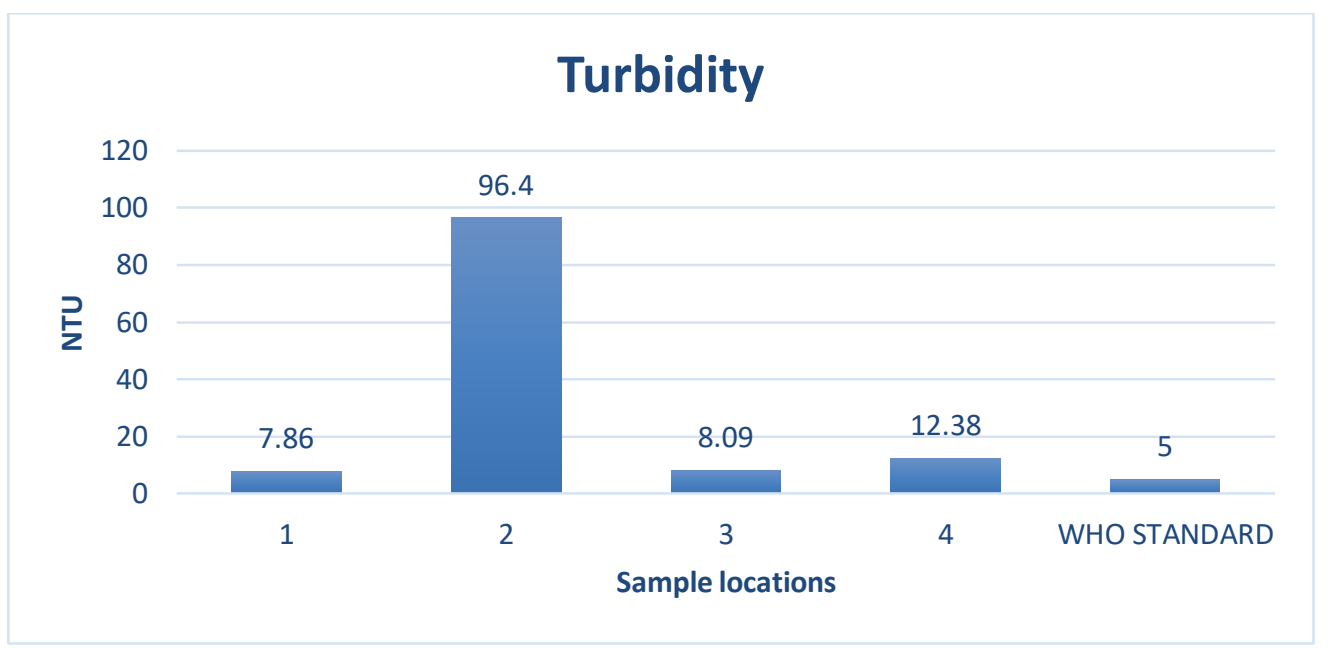

Fig 4.1: Turbidity compared with standard

CONDUCTIVITY: Electrical conductivity values for locations 1 and 2 (upstream and midstream respectively) were significantly higher than values for locations 3 and 4 (midstream and downstream respectively). The high conductivity values for locations 1 and 2 was probably due to the impact of dissolved substances from municipal wastes dumped into the river, and also industrial effluent channelled into the water body. Other contributing factors are high turbidity and extent of mineralization, see figure 4.2 below.

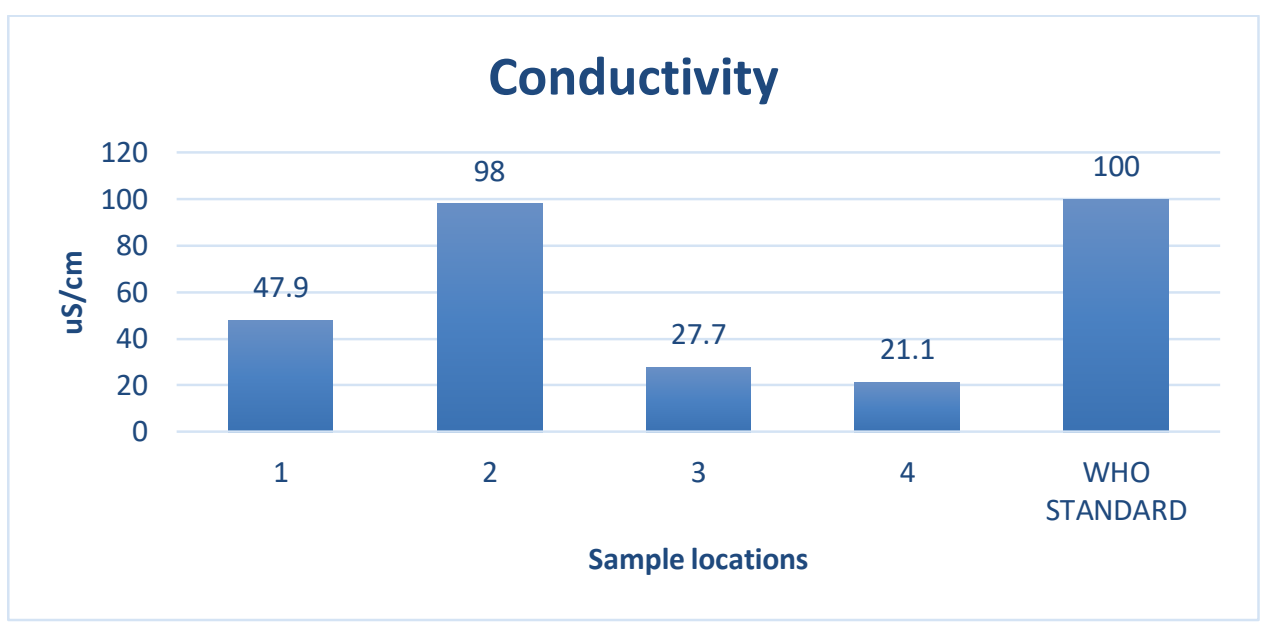

Fig 4.2: Conductivity compared with standard

TOTAL DISSOLVED SOLIDS (TDS): The total dissolved solids varied spatially and temporally. The TDS values were within permissible limit. Water samples from areas which its TDS value are higher than its permissible limit can only be used for domestic animals such as poultry, pigs and cattle that have higher TDS limits. TDS can have an important effect on taste of drinking water.

PH: The mean $\mathrm{pH}$ value of this season water samples (6.61) fell within the stipulated limits of $6.0-8.5$ for drinking water. However, the range of $\mathrm{pH}$ values observed in the study area is lower than the range reported for some Nigeria rivers such as River Asa (6.8 - 8.9) [6]; River Kaduna (6.4 - 7.2).
The lower $\mathrm{pH}$ values obtained in the study area could be linked to the predominant soil type in the river [7] or probably due to built-up of organic material. As organic substance decay, carbon dioxide forms and combines with water to produce weak acid "carbonic" acid. Some fish cannot tolerate low $\mathrm{pH}$ [4], and $\mathrm{pH}$ has synergistic effect on heavy metal toxicity.

TOTAL HARDNESS: Total hardness values fell within the limit of $500 \mathrm{mg} / \mathrm{l}$. Thus the water will not precipitate soap and the deposition of scale and incrustations accumulating in containers will be highly minimized.

NITRATE: Nitrate concentrations varied with the sampling locations and were all below 10mg/l limit 
at all locations, see figure 4.3. The implications of river waters having high $\mathrm{NO}_{3}{ }^{-}$concentrations is the stimulation of the growth of plankton and water weeds that provide food for fish. If algae grow too widely, oxygen levels will be reduced and fish will die.

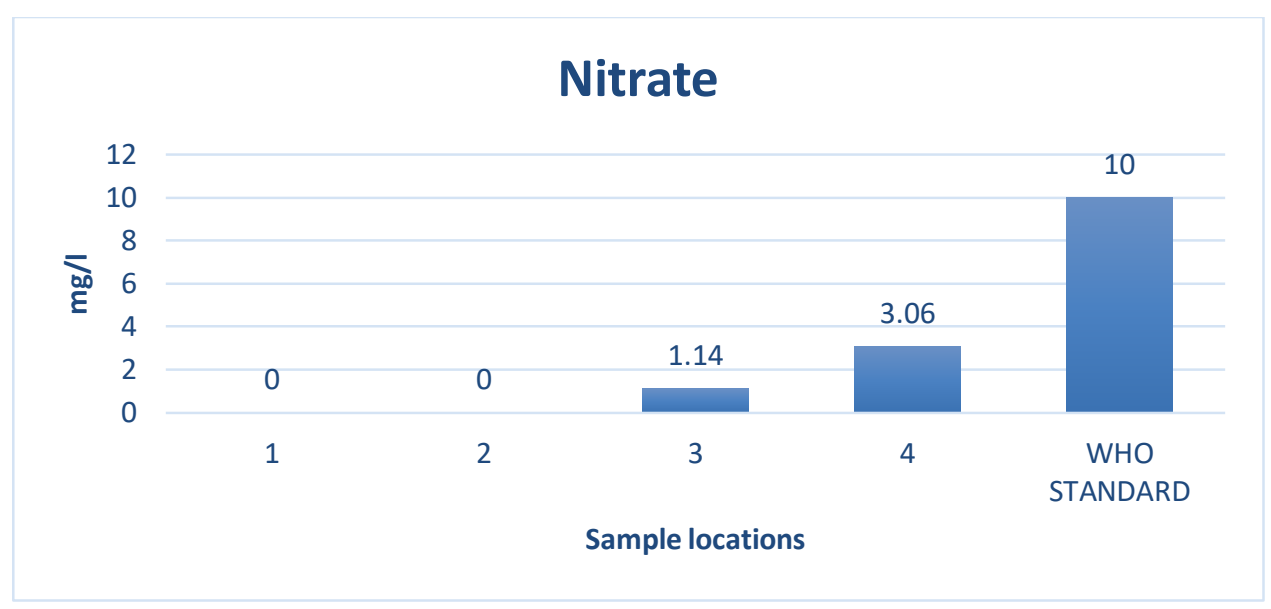

Fig 4.3: Nitrate compared with standard

PHOSPHATE: The $\mathrm{PO}_{4}{ }^{3-}$ levels varied along the sampling locations with areas close to the source of the river (1) having lower values than the midstream (2 and 3) and downstream (4). The range of values obtained in this study agrees with the moderate to high levels of $\mathrm{PO}_{4}{ }^{3-}$ in Southern Nigeria Rivers. For examples, [8] recorded a range of phosphate value of $0.01-7.40 \mathrm{mg} / \mathrm{l}$ for Yelwa
River in Southern Nigeria. However, all the values were higher than the permissible limit of $0.1 \mathrm{mg} / \mathrm{l}$ as show in figure 4.4 below. Another factor that could contribute to this phenomenon is the input of $\mathrm{PO}_{4}$ from detergents used in various car wash centres close to the river. Although phosphates are not toxic and do not represent a direct threat to animals and other organisms, they do represent a serious indirect threat to water quality.

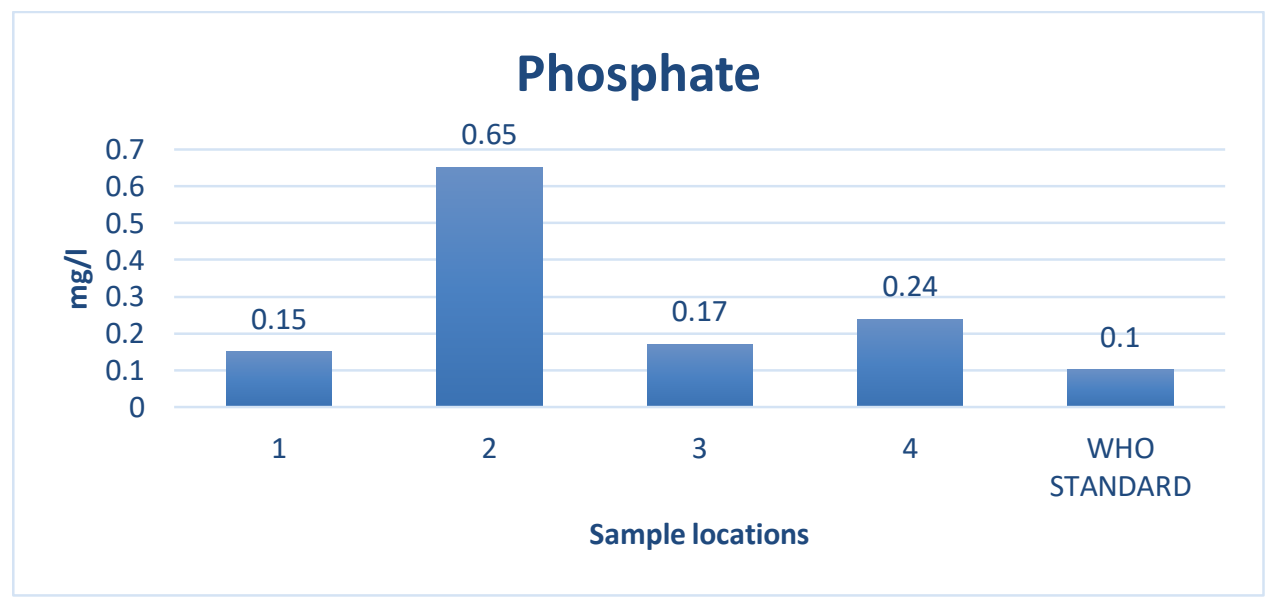

Fig.4.4: Phosphate compared with standard

SULPHATE: The general concentrations of $\mathrm{SO}_{4}{ }^{2-}$ from this study were within the $200 \mathrm{mg} / \mathrm{l}$ limit, figure 4.5. The levels were not detected along the sampling points with the midstream (2) having the only value. Sources of $\mathrm{SO}_{4}{ }^{2-}$ to the water could be from effluents from industries, runoffs, dumpsites and organic matter decomposition. When compared with the data from other studies in Southern Nigeria, the present findings show some variations. 
International Journal of Engineering Applied Sciences and Technology, 2021

Vol. 6, Issue 2, ISSN No. 2455-2143, Pages 184-191

Published Online June 2021 in IJEAST (http://www.ijeast.com)

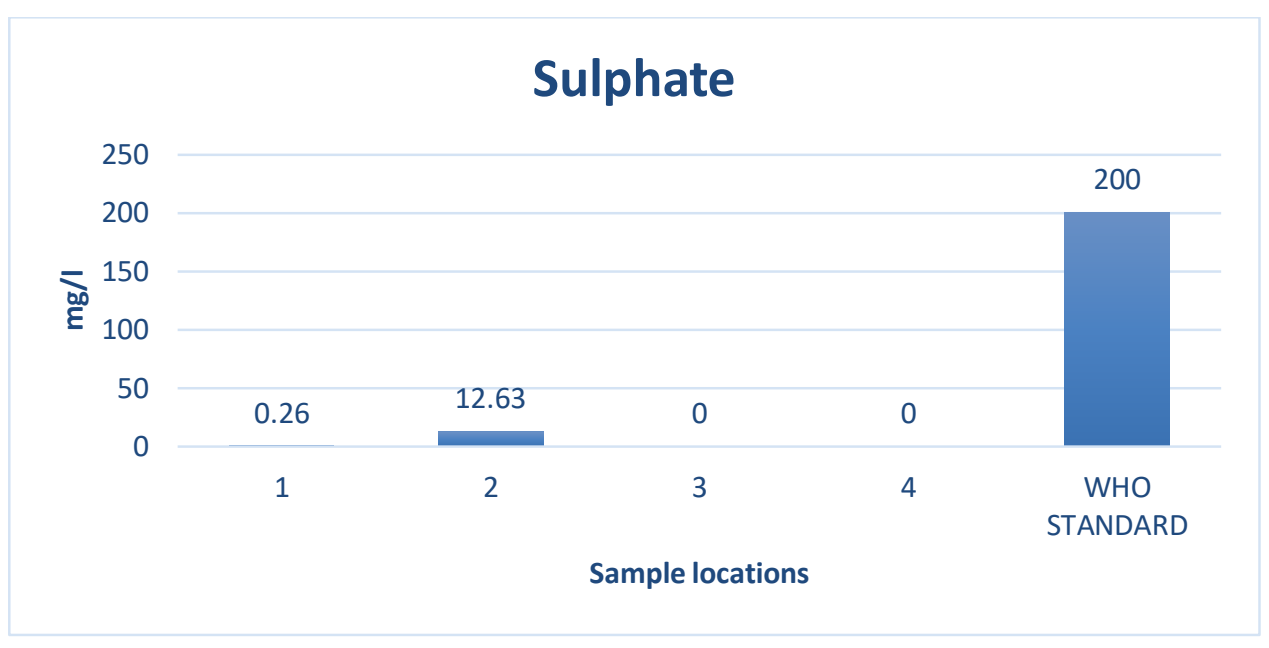

Fig 4.5: Sulphate compared with standard

CHLORIDE: Chloride concentration was generally below the permissible limit $(250 \mathrm{mg} / \mathrm{l})$. Although there were inputs of pollutants from municipal wastes into the river, the level was not high enough to significantly increase chloride level above the limit. Thus, the negative impact of high concentration of chloride in water such as causing canned or frozen food to taste "funny", killing of aquatic lives and giving salty taste to water will not be experienced.

TOTAL SUSPENDED SOLIDS (TSS): The total suspended solids varied spatially and temporally. The TSS values were way above the permissible limit, except for location 1 where the sample was lower than the limit $(50 \mathrm{mg} / \mathrm{l})$ recommended for drinking water. Water samples from this area can only be used for domestic animals such as poultry, pigs and cattle that have higher TSS limits.

ALKALINITY: Alkalinity measures the substances in water that have "acid-neutralizing" ability, or the capacity of the water to neutralize acid. It indicates a solutions power to react with acid and "buffer" its $\mathrm{pH}$. Data from this study show that the levels of alkalinity of the water samples were within the stipulate limit of $200 \mathrm{mg} / \mathrm{l}$. The low level of the parameter indicates that the underlying rocks which is the main source of natural alkalinity, probably contains low carbonate, biocarbonate, and hydroxide. Otamiri river water would therefore not have bitter taste and precipitate on pipes resulting from reaction between alkalinity and certain cations.

LEAD: Lead concentrations were not detected in the samples and therefore were within the standard guideline in samples from all the locations. Traces of lead and other heavy metals have been identified as deleterious to aquatic ecosystem and human health.

BOD5: The BOD values from all the locations were higher than $4.0 \mathrm{mg} / \mathrm{l}$ standard limit. Based on the values of the BOD reported in the upstream (locations 1), midstream (locations 2 and 3) and downstream (location 4), water in these areas can be classified as polluted. Because the oxygen demand probably exceeded the available oxygen.

COD: The COD values from all the locations were higher than $40 \mathrm{mg} / \mathrm{l}$ standard limit except for the upstream point (location 1). Based on the values of the COD reported in the midstream (locations 2 and 3 ) and downstream (location 4), water in these areas can be classified as polluted.

\section{CONCLUSION}

The first objective of this study was to examine the water quality of Otamiri River for municipal uses and to evaluate the influence of urban land use activities on the water quality. After the examination, it was deducted that rivers draining the urban environment are negatively impacted by various land use activities in the area. This study also analyzed the physical, biological and chemical contents of the water. It demonstrates the influence of urban land use on water quality indicators of Otamiri River. The data clearly show that areas outside the influence of urban activities (location 1) still maintain their pristine environmental conditions with water quality parameters falling within permissible limits. The water from these areas can sustain aquatic life and are safe for human consumption. However, areas affected by inputs from urban activities (locations 2 and 3 ) were polluted, and parameters such as TDS, BOD, COD etc, having values above stipulated standards. Water in these affected areas is not portable and is 
harmful to the aquatic ecosystem. A management plan to restrict the dumping of wastes into the Otamiri River is needed in order to reduce the impact on water quality and pollution-related health problems. This can be achieved through effective waste management strategy and provision of reliable public water supply.

\section{REFERENCES}

[1] APHA (1995). Standard Methods for the Examination of Water and Waste Water. 19th Edition, APHA-AWWA-WPCF. Washington DC. Pp 2.8-4.45.

[2] World Health Organization (2004). "Consensus of the Meeting: Nutrient minerals in drinkingwater and the potential health consequences of long-term consumption of demineralized and remineralized and altered mineral content of drinking-waters."Rolling Revision of the WHO Guidelines for Drinking-Water Quality (draft). From November 11-13, 2003 meeting in Rome, Italy at the WHO European Centre for Environment and Health.

[3] Franson, M.A. (1975). Standard Methods for the Examination of Water and Waste Water. 4th Ed: APHA-AWA-WPCF.

[4] EPA. United State Environmental Protection Agency (USEPA) quality Criteria for Water \#440/5- 86-001 (1976).

[5] Park, K. (2009). Park's Textbook of Preventive and Social Medicine. India, M/S Banarsidas Bhanot Pub. Pp. 659-661.

[6] Adeniji, H.A. (1990). Preliminary Study of the Fisheries Limnology of Bakolori Lake Nigeria. Report Presented to Sokoto Rima River Basin Dev. Authority.

[7] Ajayi S.O. and Osibanjo, O. (1984). Pollution Studies in Nigerian Rivers 11: Water quality for some Nigerian Rivers. Environ. Poll. (Series B) 1st of ED2: 87-97.

[8] Okeke P.N. and Adinna E.N. (2013). Water Quality Study of Otamiri River in Owerri, Nigeria. Universal Journal of Environmental Research and Technology, 3 (3\&6), 641-648.

[9] Njoku G. and Osondu A (2007). New Standard for Drinking Water Quality in Nigeria to Ensure the Safety of Drinking Water and Project Public Health. $\quad$ http://www.uniceff.org/nigeria/wash2165.html.
[10] Ideriah, T.J.K, Amachree O. and Stanley H.O. (2010). Assessment of Water Quality along Amadi Creek in Port Harcourt, Nigeria. Scientia Africana. 9(1): 150-162.

[11] Kegley, E.S. and Andrew, J. (1998). The Chemistry of Water. 2nd Edition, California: University Science Books, Pp 13-162.

[12] Narayana P. (2009). Environmental Pollution. Principles, Analysis and Control. CBC Pub. Limited, New Delhi. Pp 124 - 154.

[13] Linsley, Ray K. \&Franzini, Joseph B. Water Resources Engineering (1972) McGraw-Hill ISBN 0-07-037959-9 pp.454-456.

[14] Kistemann, T. ClaBen, T., Roch, C., Dangendorf, F., Fischede, R., Gebel, J., Vacata, V., and Exner, M. (2002). Microbial Load of Drinking Water Reservoir Tributaries during Extreme Rainfall and Runnoff. App. Enviro. Microbiol 68: 2188- 2197.

[15] Franson, M. A. (1975). Standard Methods for the Examination of Water and Wastewater 14th ed. Washington, DC: American Public Health Association, American Water Works Association \& Water Pollution Control Federation. ISBN 0-87553078-8. 